\title{
Percutaneous Adrenal Radiofrequency Ablation: A Short Review for Endocrinologists
}

\author{
Byung Kwan Park \\ Department of Radiology, Samsung Medical Center, Sungkyunkwan University School of Medicine, Seoul, Korea
}

Image-guided radiofrequency ablation (RFA) has been accepted as a minimally invasive treatment for adrenal tumors in patients who are unable to undergo adrenalectomy. Accordingly, this treatment has become more readily available for treating functioning or non-functioning adrenal masses. Thus, endocrinologists need a better understanding of percutaneous RFA of adrenal tumors. The purpose of this review is to briefly describe the basic mechanism of RFA, indications and contraindications, patient preparation prior to RFA, type of complications, how to avoid complications, RFA procedures, and treatment outcomes.

Keywords: Adrenal gland neoplasms; Radiofrequency ablation; Multidetector computed tomography

\section{INTRODUCTION}

Percutaneous thermal ablation is a minimally invasive treatment for liver [1,2], kidney [3,4], lung [5,6], bone [7,8], and thyroid $[9,10]$ tumors in patients who are unable to undergo surgery. This treatment also has been used to treat adrenal tumors in patients who are poor surgical candidates [11-23]. Thermal ablation techniques for adrenal ablation include radiofrequency ablation (RFA), cryoablation [24,25], and microwave ablation [26,27]. Among these techniques, RFA is most commonly used for adrenal tumors because it creates small ablation zone enough to cover small adrenal tumors.

The purpose of this review is to briefly describe the basic mechanism of RFA, indications and contraindications, patient preparations prior to RFA, type of complications, how to avoid complications, RFA procedures, and treatment outcomes.

\section{BASIC MECHANISM}

RFA elevates the temperature of tumor cells, leading to coagulative necrosis [28-31]. Alternating current is created by a radiofrequency generator and is delivered to the tumor through the electrode, which has an uninsulated tip that transmits electrical current to adjacent tissue [28-31]. Ions around the electrode tip vibrate when rapid alternating current is applied and heat energy is produced through ionic agitation. The frictional energy results in increasing tissue temperature and cell proteins begin to denature. The size of the RFA area depends on the electrical conductivity of tumor tissue around the electrode.

Internally-cooled RFA devices usually consist of an electrode, generator, pump, and pad [28-31]. Alternating current is created by the generator and is delivered to the electrode. The pump circulates normal saline to cool the electrode and improve electrical conductivity in the tumor tissue. The grounding pad is applied to the patient's thigh or body.
Received: 23 October 2020, Revised: 5 November 2020,

Accepted: 9 November 2020

Corresponding author: Byung Kwan Park

Department of Radiology, Samsung Medical Center, Sungkyunkwan University School of Medicine, 81 Irwon-ro, Gangnam-gu, Seoul 06351, Korea

Tel: +82-2-3410-6457, Fax: +82-2-3410-0084, E-mail: rapark@skku.edu
Copyright $(2020$ Korean Endocrine Society

This is an Open Access article distributed under the terms of the Creative Commons Attribution Non-Commercial License (https://creativecommons.org/ licenses/by-nc/4.0/) which permits unrestricted non-commercial use, distribution, and reproduction in any medium, provided the original work is properly cited. 


\section{INDICATIONS AND CONTRAINDICATIONS}

Total or partial adrenalectomy is the treatment of choice for adrenal tumors [32-34]; RFA should be accepted as an alternative in patients who cannot undergo surgery due to high risk of postoperative morbidity or mortality [22,23,34-40]. Moreover, recurrent pheochromocytomas in patients with hereditary diseases such as von Hippel Lindau disease or multiple endocrine neoplasms may be treated with RFA because repeat adrenalectomy cannot avoid adrenal insufficiency.

RFA candidates should have a platelet count greater than 50,000 and an international normalized ratio less than 1.5 to 1.8 [22]. Bleeding tendency or coagulopathy should be corrected prior to RFA. Non-steroid anti-inflammatory or anti-coagulant medications should be stopped at least 1 week prior to RFA. Fever is a contraindication and thus should be controlled prior to RFA.

\section{PATIENT PREPARATION}

Hypertensive crisis is frequently encountered during RFA procedures due to excessive excretion of catecholamines from the ablated adrenal medulla [41-45]. Theoretically, this complication is more severe in patients with pheochromocytomas producing epinephrine and norepinephrine [46-49]. Two or three weeks prior to RFA, these patients should undergo preoperative blockade to prevent peri-procedural (or intra-procedural) cardiovascular complications and blood pressure (BP) control. Alpha blockers are recommended as the first choice. If tachycardia develops, then $\beta$-blockers should be administered.

General anesthesia is essential to precisely target the lesion and to safely control pain or BP. Hormone-excreting adrenal masses are frequently small in size and precise targeting is important [22]. Conscious sedation is not as advantageous for precise lesion targeting or safe control of pain or BP.

An arterial line should be secured to keep monitoring BP because of the possibility of rapid hemodynamic changes [41-45]. Anesthesiologists should have alpha blockers prepared in a syringe to intravenously inject as soon as rapid increases in BP are detected. Also, interventional radiologists should be ready to turn off the radiofrequency generator because hypertensive crises may not be well controlled with intravenous medication alone.

Percutaneous biopsy is not necessary for histologic diagnosis of functioning adrenal masses such as aldosterone- or cortisolproducing adenomas and pheochromocytomas; biochemical tests and imaging features are sufficient [22]. Image-guided biopsy is necessary only for patients with primary or secondary malignant adrenal tumors.

\section{COMPLICATIONS AND PREVENTION}

Major complications requiring hospital stay or intervention are not common, ranging from $0 \%$ to $8.3 \%$ (median, $1.5 \%$ ) [11-18]. Hypertensive crisis is the most common complication during the procedure and rapid increases in BP may complicate cerebrovascular and cardiovascular diseases (Fig. 1) [41-45]. Appropriate medication is necessary to prevent hypertensive crisis prior to or during RFA procedures [50-53]. Interventional radiologists should be ready to turn off the generator during RFA procedures because BP is not well controlled due to excessive excretion of catecholamines.

Pneumothorax is a common complication when the lung parenchyma is intervened between the skin and adrenal tumor [20,37-40,54]. A transhepatic approach provides another access route to reach right adrenal masses without lung injury when a patient is supine [22,37-40]. If the right or left side of the patient's body is down, the ipsilateral lung tends to be collapsed. This position change is very useful to avoid pneumothorax when a patient is prone.

Bowel injury occurs when the tumor-to-bowel distance is less than approximately $5 \mathrm{~mm}[22,37-40]$. Patient' position change or levering a radiofrequency electrode may displace the tumor away from the bowel. When this does not work, hydrodissection can displace the bowel by means of instilling fluid between the tumor and bowel.

Bleeding is a common complication (Fig. 1) and meticulous manipulation of the radiofrequency electrode is one way to reduce this complication [22,37-40]. However, avoiding major organs is the best way to prevent serious bleeding [22,37-40].

Adrenal insufficiency has been reported as a rare complication following RFA [22,37-40]. Partial adrenalectomy is also useful for avoiding this complication, but is inferior to RFA in terms of preserving adrenal function. Further investigation is needed to compare the adrenal function outcomes of RFA and partial adrenalectomy.

\section{RFA PROCEDURES}

Computed tomography (CT) is the best imaging modality to guide adrenal RFA procedures [22,37-40]. Therefore, a ventilator and oxygen for general anesthesia should be available in the 

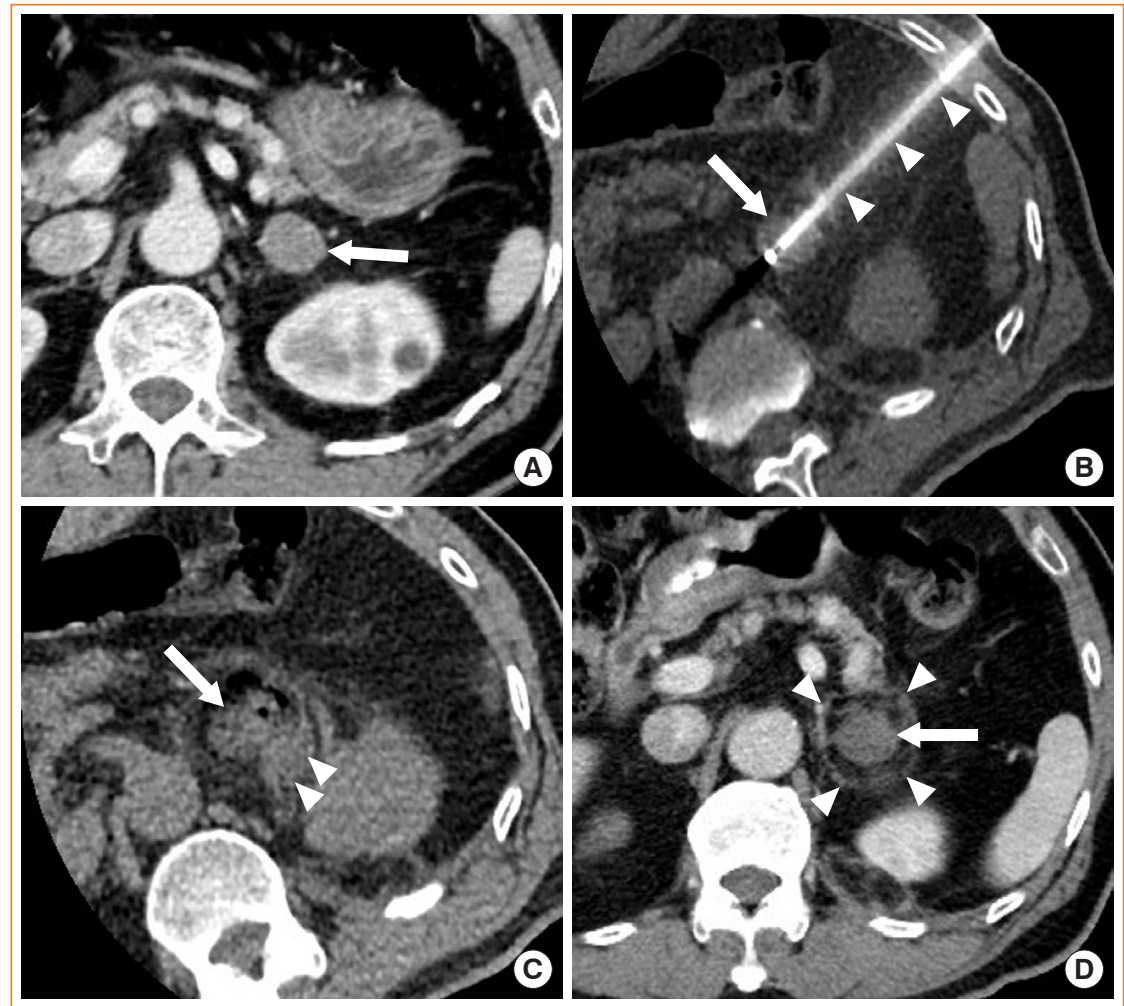

Fig. 1. A 60-year-old man with aldosterone-producing adenoma. (A) Contrast-enhanced axial computed tomography (CT) image shows a $2.5 \mathrm{~cm}$ left adrenal adenoma (arrow) with good enhancement. Adrenalectomy was failed because of severe adhesion which had developed since left hemicolectomy was performed to treat descending colon cancer. (B) Unenhanced axial CT image obtained during ablation procedures shows a radiofrequency electrode (arrowheads), which is advanced via left intercostal space and placed in the center of the left adrenal adenoma (arrow). (C) Unenhanced axial CT image obtained immediately after ablation was finished shows a small amount of acute hematoma (arrowheads) around the left adrenal adenoma (arrow). Hypertensive crisis occurred three times, but was well controlled with intermittent intravenous injection of alpha blockers. But also, turning off the power of generator was added to the medication in the first cycle of ablation. (D) Contrast-enhanced CT image obtained 1 month after ablation was finished shows no enhancement within the left adrenal adenoma (arrow). Arrowheads indicate the margin of ablation zone. His aldosterone-to-renin ratio was 471.58 before ablation and 5.27 after ablation. However, his blood pressure was reduced, but still ranged slightly higher.

CT room. Ultrasound does not provide a good sonic window to access adrenal masses because the lesions are too deep and too small to target. Magnetic resonance imaging (MRI) does not achieve clear imaging of RFA procedures because the electrical current disturbs magnetic field, resulting in MRI distortion or artifacts. Moreover, MRI-compatible RFA devices are not commercially available.

RFA procedures comprise three steps: planning, targeting, and monitoring (Fig. 1) [55]. Planning involves locating the tumor and determining the skin entry site. Targeting is the second step, to place single or multiple electrodes within the tumor. Monitoring is the last step to determine whether the tumor and tumor margin are completely ablated and whether there are significant RFA complications.

\section{RFA OUTCOMES}

Percutaneous RFA provides excellent clinical and hormonal outcomes for patients with functional benign adrenal masses such as aldosteronoma, cortisol-secreting adenoma, and pheochromocytoma (Table 1) $[11,14-17,19,20]$. The most common functioning benign tumor treated is aldosteronoma. The number of cortisol-secreting adenomas or pheochromocytomas treated with RFA is much smaller than that of aldosteronomas [14-17,19,20]. Short- and long-term bio-chemical resolution have ranged from $90 \%$ to $100 \%$ (median, $100 \%$ ) (Table 1) $[11,14-17,19,20]$. Normalization of aldosterone, renin, and aldosterone to renin ratio have been achieved in almost all cases of aldosteronoma [1417,20]. However, persistent hypertension even after hormones are normalized is not uncommon (Fig. 1) [14,15,17,20]. 
Table 1. Radiofrequency Ablation Outcomes of Functioning Adrenal Masses

\begin{tabular}{lclcc}
\hline Investigators & No. of cases & Clinical diagnoses & Mean FU period, mo & Biochemical resolution, \% \\
\hline Arima et al. [11] & 4 & Cushing's syndrome $(n=4)$ & 33 & $100(4 / 4)$ \\
Liu et al. [14] & 36 & Aldosteronoma $(n=36)$ & 74 & $100(36 / 36)$ \\
Mendiratta-Lala et al. [16] & 13 & Aldosteronoma $(n=10)$ etc. & 21.2 & $100(13 / 13)$ \\
Szejnfeld et al. [17] & 11 & Aldosteronoma $(n=9)$ etc. & 3 & $100(11 / 11)$ \\
Nunes et al. [20] & 11 & Aldosteronoma $(n=9)$ etc. & Not reported & $90(9 / 10)$ \\
\hline FU, follow-up. & & & & \\
\hline
\end{tabular}

Table 2. Radiofrequency Ablation Outcomes of Adrenal Metastasis

\begin{tabular}{lcccc}
\hline Investigators & No. of cases (masses) & Mean/median size, cm & Mean FU period, mo & Local control, \% \\
\hline Hasegawa et al. [12] & $35(41)$ & 3.3 & 30.1 & $77.0(27 / 35)$ \\
Huang et al. [13] & $22(22)$ & 4.0 & 12.0 & $77.3(17 / 22)$ \\
Zhou et al. [18] & $33(38)$ & 3.0 & 27.4 & $78.9(30 / 38)$ \\
Mouracade et al. [21] & $5(5)$ & 3.9 & 12.0 & $80(4 / 5)$ \\
\hline FU, follow-up. & & & & \\
\hline
\end{tabular}

RFA outcomes for treating adrenal metastasis are not as good as those for benign adrenal tumors (Table 2) [12,13,18,21]. The local control rate ranges from $77 \%$ to $80 \%$ (median, $78 \%$ ). These treatment outcomes may depend on metastatic tumor size, which is larger, ranging from 3.3 to $4.0 \mathrm{~cm}$ (Table 2) [12,13,18, $21,22]$. Because cryoablation or microwave ablation can create a larger ablation area, these modalities should be considered for treating adrenal masses $3 \mathrm{~cm}$ or larger. Overall survival rate is poor because adrenal metastasis indicates stage IV disease, even in cases with a single metastatic tumor [12,13,18,21,22]. RFA outcomes for treating adrenocortical carcinoma are rarely reported because adrenalectomy is the treatment of choice for the primary adrenal cancer.

\section{CONCLUSIONS}

Percutaneous RFA is a safe and effective minimally invasive treatment for benign functioning adrenal tumors. This treatment technique also provides relatively good local control in patients with adrenal metastasis. Thus, RFA is a good alternative treatment in patients who are poor candidates for adrenalectomy.

\section{CONFLICTS OF INTEREST}

No potential conflict of interest relevant to this article was reported.

\section{ORCID}

Byung Kwan Park https://orcid.org/0000-0002-4114-8859

\section{REFERENCES}

1. Livraghi T, Goldberg SN, Lazzaroni S, Meloni F, Solbiati L, Gazelle GS. Small hepatocellular carcinoma: treatment with radio-frequency ablation versus ethanol injection. Radiology 1999;210:655-61.

2. Livraghi T, Goldberg SN, Lazzaroni S, Meloni F, Ierace T, Solbiati L, et al. Hepatocellular carcinoma: radio-frequency ablation of medium and large lesions. Radiology 2000;214: 761-8.

3. Gervais DA, McGovern FJ, Wood BJ, Goldberg SN, McDougal WS, Mueller PR. Radio-frequency ablation of renal cell carcinoma: early clinical experience. Radiology 2000; 217:665-72.

4. Gervais DA, McGovern FJ, Arellano RS, McDougal WS, Mueller PR. Radiofrequency ablation of renal cell carcinoma: part 1, Indications, results, and role in patient management over a 6-year period and ablation of 100 tumors. AJR Am J Roentgenol 2005;185:64-71.

5. Lee JM, Jin GY, Goldberg SN, Lee YC, Chung GH, Han YM, et al. Percutaneous radiofrequency ablation for inoperable non-small cell lung cancer and metastases: preliminary 
report. Radiology 2004;230:125-34.

6. Fernando HC, De Hoyos A, Landreneau RJ, Gilbert S, Gooding WE, Buenaventura PO, et al. Radiofrequency ablation for the treatment of non-small cell lung cancer in marginal surgical candidates. J Thorac Cardiovasc Surg 2005; 129:639-44.

7. Nakatsuka A, Yamakado K, Maeda M, Yasuda M, Akeboshi M, Takaki H, et al. Radiofrequency ablation combined with bone cement injection for the treatment of bone malignancies. J Vasc Interv Radiol 2004;15:707-12.

8. Ruiz Santiago F, Castellano Garcia Mdel M, Guzman Alvarez L, Martinez Montes JL, Ruiz Garcia M, Tristan Fernandez JM. Percutaneous treatment of bone tumors by radiofrequency thermal ablation. Eur J Radiol 2011;77:156-63.

9. Jeong WK, Baek JH, Rhim H, Kim YS, Kwak MS, Jeong $\mathrm{HJ}$, et al. Radiofrequency ablation of benign thyroid nodules: safety and imaging follow-up in 236 patients. Eur Radiol 2008; 18:1244-50.

10. Na DG, Lee JH, Jung SL, Kim JH, Sung JY, Shin JH, et al. Radiofrequency ablation of benign thyroid nodules and recurrent thyroid cancers: consensus statement and recommendations. Korean J Radiol 2012;13:117-25.

11. Arima K, Yamakado K, Suzuki R, Matsuura H, Nakatsuka A, Takeda K, et al. Image-guided radiofrequency ablation for adrenocortical adenoma with Cushing syndrome: outcomes after mean follow-up of 33 months. Urology 2007;70:40711.

12. Hasegawa T, Yamakado K, Nakatsuka A, Uraki J, Yamanaka T, Fujimori M, et al. Unresectable adrenal metastases: clinical outcomes of radiofrequency ablation. Radiology 2015; 277:584-93.

13. Huang J, Xie X, Lin J, Wang W, Zhang X, Liu M, et al. Percutaneous radiofrequency ablation of adrenal metastases from hepatocellular carcinoma: a single-center experience. Cancer Imaging 2019;19:44.

14. Liu SY, Chu CC, Tsui TK, Wong SK, Kong AP, Chiu PW, et al. Aldosterone-producing adenoma in primary aldosteronism: CT-guided radiofrequency ablation-long-term results and recurrence rate. Radiology 2016;281:625-34.

15. Liu SY, Ng EK, Lee PS, Wong SK, Chiu PW, Mui WL, et al. Radiofrequency ablation for benign aldosterone-producing adenoma: a scarless technique to an old disease. Ann Surg 2010;252:1058-64.

16. Mendiratta-Lala M, Brennan DD, Brook OR, Faintuch S, Mowschenson PM, Sheiman RG, et al. Efficacy of radiofrequency ablation in the treatment of small functional adrenal neoplasms. Radiology 2011;258:308-16.

17. Szejnfeld D, Nunes TF, Giordano EE, Freire F, Ajzen SA, Kater CE, et al. Radiofrequency ablation of functioning adrenal adenomas: preliminary clinical and laboratory findings. J Vasc Interv Radiol 2015;26:1459-64.

18. Zhou K, Pan J, Yang N, Shi HF, Cao J, Li YM, et al. Effectiveness and safety of CT-guided percutaneous radiofrequency ablation of adrenal metastases. Br J Radiol 2018;91: 20170607.

19. Liu SY, Chu CM, Kong AP, Wong SK, Chiu PW, Chow FC, et al. Radiofrequency ablation compared with laparoscopic adrenalectomy for aldosterone-producing adenoma. Br J Surg 2016;103:1476-86.

20. Nunes TF, Szejnfeld D, Xavier AC, Kater CE, Freire F, Ribeiro CA, et al. Percutaneous ablation of functioning adrenal adenoma: a report on 11 cases and a review of the literature. Abdom Imaging 2013;38:1130-5.

21. Mouracade P, Dettloff H, Schneider M, Debras B, Jung JL. Radio-frequency ablation of solitary adrenal gland metastasis from renal cell carcinoma. Urology 2009;74:1341-3.

22. Uppot RN, Gervais DA. Imaging-guided adrenal tumor ablation. AJR Am J Roentgenol 2013;200:1226-33.

23. Liang KW, Jahangiri Y, Tsao TF, Tyan YS, Huang HH. Effectiveness of thermal ablation for aldosterone-producing adrenal adenoma: a systematic review and meta-analysis of clinical and biochemical parameters. J Vasc Interv Radiol 2019;30:1335-42.

24. Welch BT, Atwell TD, Nichols DA, Wass CT, Callstrom MR, Leibovich BC, et al. Percutaneous image-guided adrenal cryoablation: procedural considerations and technical success. Radiology 2011;258:301-7.

25. Fu YF, Cao C, Shi YB, Zhang W, Huang YY. Computed tomography-guided cryoablation for functional adrenal aldosteronoma. Minim Invasive Ther Allied Technol 2019:1-5.

26. Li X, Fan W, Zhang L, Zhao M, Huang Z, Li W, et al. CTguided percutaneous microwave ablation of adrenal malignant carcinoma: preliminary results. Cancer 2011;117:51828.

27. Ren C, Liang P, Yu XL, Cheng ZG, Han ZY, Yu J. Percutaneous microwave ablation of adrenal tumours under ultrasound guidance in 33 patients with 35 tumours: a singlecentre experience. Int J Hyperthermia 2016;32:517-23.

28. Hong K, Georgiades C. Radiofrequency ablation: mechanism of action and devices. J Vasc Interv Radiol 2010;21: S179-86.

29. Goldberg SN, Gazelle GS. Radiofrequency tissue ablation: 
physical principles and techniques for increasing coagulation necrosis. Hepatogastroenterology 2001;48:359-67.

30. Goldberg SN. Radiofrequency tumor ablation: principles and techniques. Eur J Ultrasound 2001;13:129-47.

31. Ahmed M, Brace CL, Lee FT Jr, Goldberg SN. Principles of and advances in percutaneous ablation. Radiology 2011;258: 351-69.

32. Lee JM, Kim MK, Ko SH, Koh JM, Kim BY, Kim SW, et al. Clinical guidelines for the management of adrenal incidentaloma. Endocrinol Metab (Seoul) 2017;32:200-18.

33. Fassnacht M, Arlt W, Bancos I, Dralle H, Newell-Price J, Sahdev A, et al. Management of adrenal incidentalomas: European Society of Endocrinology Clinical Practice Guideline in collaboration with the European Network for the Study of Adrenal Tumors. Eur J Endocrinol 2016;175:G1-34.

34. Bednarczuk T, Bolanowski M, Sworczak K, Gornicka B, Cieszanowski A, Otto M, et al. Adrenal incidentaloma in adults: management recommendations by the Polish Society of Endocrinology. Endokrynol Pol 2016;67:234-58.

35. Sahdev A. Recommendations for the management of adrenal incidentalomas: what is pertinent for radiologists? $\mathrm{Br} \mathrm{J}$ Radiol 2017;90:20160627.

36. Thomas AZ, Blute ML Sr, Seitz C, Habra MA, Karam JA. Management of the incidental adrenal mass. Eur Urol Focus 2016;1:223-30.

37. Beland MD, Mayo-Smith WW. Ablation of adrenal neoplasms. Abdom Imaging 2009;34:588-92.

38. Ethier MD, Beland MD, Mayo-Smith W. Image-guided ablation of adrenal tumors. Tech Vasc Interv Radiol 2013;16: 262-8.

39. Venkatesan AM, Locklin J, Dupuy DE, Wood BJ. Percutaneous ablation of adrenal tumors. Tech Vasc Interv Radiol 2010;13:89-99.

40. Yamakado K. Image-guided ablation of adrenal lesions. Semin Intervent Radiol 2014;31:149-56.

41. Chini EN, Brown MJ, Farrell MA, Charboneau JW. Hypertensive crisis in a patient undergoing percutaneous radiofrequency ablation of an adrenal mass under general anesthesia. Anesth Analg 2004;99:1867-9.

42. Keeling AN, Sabharwal T, Allen MJ, Hegarty NJ, Adam A. Hypertensive crisis during radiofrequency ablation of the adrenal gland. J Vasc Interv Radiol 2009;20:990-1.

43. Lee KJ, Ryu SH. A case of hypertensive crisis without a surge in adrenal hormones after radiofrequency ablation as a treatment for primary hepatocellular carcinoma. Korean J Gastroenterol 2017;70:198-201.

44. Ye X. Hypertensive crisis-a major complication of imageguided ablation for adrenal tumor. Zhonghua Yi Xue Za Zhi 2019;99:1121-2.

45. Zheng L, Zhou F, Yu X, Liang P, Cheng Z, Han Z, et al. Hypertensive crisis during microwave ablation of adrenal neoplasms: a retrospective analysis of predictive factors. J Vasc Interv Radiol 2019;30:1343-50.

46. Deljou A, Kohlenberg JD, Weingarten TN, Bancos I, Young WF Jr, Schroeder DR, et al. Hemodynamic instability during percutaneous ablation of extra-adrenal metastases of pheochromocytoma and paragangliomas: a case series. BMC Anesthesiol 2018;18:158.

47. Kohlenberg J, Welch B, Hamidi O, Callstrom M, Morris J, Sprung J, et al. Efficacy and safety of ablative therapy in the treatment of patients with metastatic pheochromocytoma and paraganglioma. Cancers (Basel) 2019;11:195.

48. Pappachan JM, Tun NN, Arunagirinathan G, Sodi R, Hanna FWF. Pheochromocytomas and hypertension. Curr Hypertens Rep 2018;20:3.

49. Venkatesan AM, Locklin J, Lai EW, Adams KT, Fojo AT, Pacak K, et al. Radiofrequency ablation of metastatic pheochromocytoma. J Vasc Interv Radiol 2009;20:1483-90.

50. Adams HA, Hempelmann G. Anesthesia for patients with pheochromocytoma: our own results and a review. Anasthesiol Intensivmed Notfallmed Schmerzther 1993;28:500-9.

51. Baraka A, Siddik-Sayyid S, Jalbout M, Yaacoub C. Variable hemodynamic fluctuations during resection of multicentric extraadrenal pheochromocytomas. Can J Anaesth 2002;49: 682-6.

52. Chung PC, Li AH, Lin CC, Yang MW. Elevated vascular resistance after labetalol during resection of a pheochromocytoma (brief report). Can J Anaesth 2002;49:148-50.

53. Knapp HR, Fitzgerald GA. Hypertensive crisis in prazosintreated pheochromocytoma. South Med J 1984;77:535-6.

54. Brook OR, Mendiratta-Lala M, Brennan D, Siewert B, Faintuch S, Goldberg SN. Imaging findings after radiofrequency ablation of adrenal tumors. AJR Am J Roentgenol 2011;196: 382-8.

55. Park BK, Morrison PR, Tatli S, Govindarajulu U, Tuncali K, Judy P, et al. Estimated effective dose of CT-guided percutaneous cryoablation of liver tumors. Eur J Radiol 2012;81: 1702-6. 